\title{
Epidemiological Characteristics of Meningitis Caused by Mumps virus during the epidemic In the Republic Of Srpska
}

\section{ABSTRACT}

Introduction: Mumps is a systemic viral infection characterized by swelling of salivary glands, especially the parotid ones. Gonads, meninges, pancreas and other organs may also be affected.

Aims of the study: The aim of this study was to analyze the epidemiological characteristics of mumps meningitis in the last epidemic of mumps in the Republic of Srpska, and to analyze the frequency of mumps meningitis and vaccination status in patients who were supposed to be vaccinated against mumps in the war and early post-war period, and also in those patients who were supposed to be vaccinated before or after this period.

Patients and Methods: The study included 175 patients divided in the experimental group (140 patients with mumps meningitis) and the control group (35 patients with serous meningitis of other etiology, probably enteroviral). We compared epidemiological characteristics of these patients and additionally we analyzed the differences in these characteristics in patients with different vaccination status.

Results: The mean age of patients in the experimental group was 20.0 years (18.0-24.5; IQ), and in the control group 7.0 years (5.0-14.0; IQ) ( $p<0.001)$. Patients born between 1985 and 1996 more frequently suffered from meningitis $(p<0.001)$ caused with mumps virus than other patients in the experimental group. There was no statistically significant difference in sex distribution between patients in the experimental and control group $(p=0.746)$, nor between patients in the experimental group with previously different vaccination status ( $p=0.371)$. Most patients in the experimental group didn't have data of their immunization status. The subsequent are those patients who received only one dose of vaccine, followed by unvaccinated patients and those who were vaccinated correctly.

Conclusion: The epidemic of mumps during 2011 and 2012 is a consequence of maintaining the virus in non-vaccinated population (mainly because of the omissions made during the war and early post-war period) and insufficient duration of protection after vaccination, especially in vaccination with one dose of vaccine.

Key words: mumps, meningitis, epidemic
Tatjana Roganović1, Zdravka Kezić1, Janja Bojanić ${ }^{\text {, }}$ Biljana Mijović, Ljubica Jandrić ${ }^{2}$, Nina Rodić-Vukmir ${ }^{2}$

${ }^{1}$ Infectious Diseases Clinic, University Hospital Clinical Center Banja Luka, Bosnia and Herzegovina 2 Public Health Institute of the Republic of Srpska, Banja Luka, Bosnia and Herzegovina

${ }^{3}$ Institute of Public Health Užice, Užice, Serbia

\section{Contact address:}

Tatjana Roganovic,

Bulevar Desanke Maksimovic 20 78 ooo Banjaluka

mobile phone: + 38765657305 , e-mail: tanja-roganovic@blic.ne

Submitted: January 27th, 2015 Accepted: March 4th, 2015 


\section{Introduction}

Mumps is an acute, contagious, systemic viral infection characterized by of unilateral or bilateral swelling of salivary glands, especially the parotid ones. Gonads, meninges, pancreas and other organs may also be affected.1,2 Humans are the sole reservoir for the mumps virus which is highly infectious and is spread from person to person by respiratory droplets. ${ }^{3,4}$ The peak incidence of the disease is in late winter and early spring. ${ }^{5}$ The infectious period lasts from 2 days prior to the occurrence of parotitis to 9 days afterwards. ${ }^{6}$ The period of incubation (with a maximum range of 7-25 days according to different authors) is followed by a prodromal period which lasts from 3 to 5 days and is manifested by the infectious syndrome. ${ }^{7,8}$ The evolution of mumps clinical presentation depends on the organ which is affected. The infection is asymptomatic in up to $20-30 \%$ of people, especially in children. ${ }^{3}$ People with asymptomatic infections can transmit the virus.${ }^{9}$ The mumps virus induces strong cellular and humoral immune response and the infection generally leads to lifelong immunity. The reinfection is possible, but rarely. ${ }^{10}$

Mumps virus was the leading cause of aseptic meningitis prior to widespread use of vaccines,${ }^{11}$ but nowadays the leading cause of aseptic meningitis is the enterovirus with $85-95 \%$ of all viral meningitis with proven cause.$^{12}$

In unvaccinated population, mumps virus infection usually affects children from 5 to 9 years and epidemis occur every 2-5 years. ${ }^{13}$ The number of cases of mumps decreased after the introduction of mandatory vaccination for about $95 \%$ per year. A mild increase in the number of mumps virus infection cases was registered since the second half of 1980's and this could be explained by keeping the virus alive in unvaccinated population and the insufficient duration of protection after single-dose of mumps vaccine, which was the reason why the second dose of the vaccine was introduced to a vaccination calendar (usually pre-school)..$^{10}$ The disease shifted to older age groups, adolescents and young adults. ${ }^{8}$

The most effective strategy of mumps prevention in community and health care settings is promoting high levels of vaccination. ${ }^{4}$ According to the program of measures for prevention and suppression, elimination and eradication of infectious diseases in the territory of the Republic of Srpska for 2013, mandatory vaccination against measles, mumps and rubella is administered at 12 to 15 months of age. Revaccination is at the age of 6 or 7 , when children start school. If vaccination or revaccination are not administered on time vaccine can be administered later, until the age of 19 at the latest. Minimum interval between doses is one month. ${ }^{16}$

\section{The aim of this study}

The aim of this study was to compare the epidemiological characteristics of patients with mumps meningitis and patients with serous meningitis of other, probably of enteroviral etiology, and to analyze the frequency of mumps meningitis and vaccination status in patients who were supposed to be vaccinated against mumps in the war and early post-war period, and also in those patients who were supposed to be vaccinated before or after this period.

\section{Patients and Methods}

The study is designed as a retrospective-prospective observation study. It included 175 patients treated in Infectious Diseases Clinic of the University Hospital Clinical Center Banja Luka. The patients were divided in two groups, the experimental and the control group. The experimental group was consisted of 140 patients with mumps meningitis treated from October, 2011 to December, 2012, and the control group was consisted of 35 patients with serous meningitis of other etiology, probably enteroviral, treated from June to October, 2010. In the experimental group, the diagnosis was made on the basis of epidemiological data, clinical picture, the course of the disease, blood results and cerebrospinal fluid (CSF) analysis, with additional serology tests (mumps specific IgM and IgG antibodies) and polymerase chain reaction (PCR) for detection of mumps. The diagnosis of meningitis in the control group was made on the basis of epidemiological data, clinical picture, the course of the disease, blood results and CSF analysis, with assumption that the meningitis was caused by enterovirus. That assumption was based on the number of patients and their age, the time of year when the disease appeared and on the fact that symptoms pointing to other possible etiology were not present. Etiological diagnosis of the enteroviral infection was not possible at that time.

We compared epidemiological characteristics of the patients in the experimental and control group. The listed characteristics were presented through demographic data collected from medical documentation of every patient and information of vaccination status of patients with mumps meningitis obtained from the Vaccination Centers throughout the Republic of Srpska. Additionally, we analyzed the differences in these epidemiological characteristics in patients with different vaccination status, those who were previously completely vaccinated and those who weren't. Completely vaccinated were those patients who received two doses of MMR vaccine and incompletely vaccinated were those who didn't receive any or who received only one dose of MMR vaccine.

According to the information by the Public Health Institute of the Republic of Srpska there was no regular supply of MMR vaccine in the war and early post-war period (from 1992 to 1998). That information leads to indirect conclusion of inadequate vaccination coverage for people born from 
1985 to 1996 . Based on the abovementioned information, we additionally divided 140 patients into two groups. The first group consisted of people born from 1985 to 1996, and the other group of those born before or after this period. We compared frequency ratio of first and second group with expected frequency ratio of these two age groups. The expected frequency ratio is ratio between total population of the first age group and total population of the second age group in Republic of Srpska, according to regular report of the Republic of Srpska, Institute of Statistics from 2010.

\section{Results}

Respondents from 19 different towns participated in the research (Table 1.) Table 1. shows frequency and percentage distribution of the place of residence for patients in the experimental and control group. The majority of patients were from Banja Luka (40.71\% in the experimental, and $68.57 \%$ in the control group).

Table 1. The frequency and the percentage distribution of the place of residence in the experimental and control group of patients

\begin{tabular}{lcccc}
\hline \multirow{2}{*}{ Place of residence } & \multicolumn{4}{c}{ Group } \\
\cline { 2 - 5 } & \multicolumn{2}{c}{ Experimental } & \multicolumn{2}{c}{ Control } \\
\cline { 2 - 5 } & $\mathrm{n}$ & $\%$ & $\mathrm{n}$ & $\%$ \\
\hline Banja Luka & 57 & 40.71 & 24 & 68.57 \\
\hline Čelinac & 3 & 2.14 & 0 & 0.00 \\
\hline Derventa & 2 & 1.43 & 0 & 0.00 \\
\hline Gacko & 1 & 0.71 & 0 & 0.00 \\
\hline Gradiška & 17 & 12.14 & 1 & 2.86 \\
\hline Kneževo & 7 & 5.00 & 0 & 0.00 \\
\hline Kostajnica & 3 & 2.14 & 0 & 0.00 \\
\hline Kotor Varoš & 1 & 0.71 & 0 & 0.00 \\
\hline Kozarska Dubica & 10 & 7.14 & 0 & 0.00 \\
\hline Laktaši & 3 & 2.14 & 0 & 0.00 \\
\hline Mrkonjić Grad & 2 & 1.43 & 1 & 2.86 \\
\hline Nova Topola & 1 & 0.71 & 0 & 0.00 \\
\hline Novi Grad & 10 & 7.14 & 2 & 5.71 \\
\hline Prijedor & 10 & 7.14 & 0 & 0.00 \\
\hline Prnjavor & 6 & 4.29 & 3 & 8.57 \\
\hline Ribnik & 1 & 0.71 & 2 & 5.71 \\
\hline Sanski Most & 1 & 0.71 & 0 & 0.00 \\
\hline Sokolac & 1 & 0.71 & 0 & 0.00 \\
\hline Šipovo & 4 & 2.86 & 2 & 5.71 \\
\hline Total & 140 & 100.00 & 35 & 100.00 \\
\hline
\end{tabular}

The patients in the experimental group were from 19 different cities. Besides Banjaluka, there were $12.14 \%$ patients from Gradiška, and from Kozarska Dubica, Novi Grad and Prijedor $7.14 \%$ each. The control group consisted of patients from Banjaluka, Prnjavor, Ribnik, Šipovo, Novi Grad, Gradiška and Mrkonjić Grad.
$42.14 \%$ of patients in the experimental group and $28.27 \%$ of patients in the control group confirmed that they were in contact with patients with similar symptoms. That difference between thethe groups wasn't statistically significant $(\mathrm{p}=0.142)$.

The mean age of patients in the experimental group was 20.0 years (18.0-24.5; IQ), and in the control group 7.0 years (5.0-14.0; IQ). This difference was statistically significant $(\mathrm{p}<0.001)$.

In the experimental group, $76.43 \%$ of patients were born between 1985 and 1996. According to the estimated number of population of that age in relation to the number of the rest of the population in 2010 in theRepublic of Srpska, the expected percentage of patients in that certain age in relation to all patients in the control group was $11.43 \%$. Statistically, the patients born in that period had meningitis caused by mumps virus more frequently $(\mathrm{p}<0.001)$ than other patients in the experimental group (Table 2.).

Table 2. Age distribution of patients in the experimental group in relation to the expected number of patients according to the estimated population of the Republic of Srpska

\begin{tabular}{|c|c|c|c|c|}
\hline \multirow[t]{2}{*}{ Birth period } & \multicolumn{2}{|c|}{$\begin{array}{c}\text { Experimental } \\
\text { group }\end{array}$} & \multicolumn{2}{|c|}{$\begin{array}{c}\text { The expected } \\
\text { number of patients } \\
\text { according to the } \\
\text { estimated number } \\
\text { of population }\end{array}$} \\
\hline & $\mathrm{n}$ & $\%$ & $n$ & $\%$ \\
\hline Born from 1985 to 1996 & 107 & $76.43^{*}$ & 16 & 11.43 \\
\hline The rest & 33 & 23.57 & 124 & 88.57 \\
\hline Total & 140 & 100.00 & 140 & 100.00 \\
\hline
\end{tabular}

${ }^{*} \mathrm{p}<0.001$ - experimental group vs. expected number of patients according to the estimated number of population

$68.57 \%$ of patients in the experimental group were men, there was no statistically significant difference in gender distribution between patients in the experimental and the control group $(\mathrm{p}=0.746)$. There was no statistically significant difference in sex distribution in the experimental group of patients with known vaccination status between patients who were adequately vaccinated, inadequately vaccinated or who were unvaccinated against mumps $(\mathrm{p}=0.371)$ (Table 3.).

For most patients from the studied group, 51.43\%, immunization records were unavailable. There were $24.29 \%$ patients who received only one dose of vaccine and $17,14 \%$ unvaccinated. There were the least of patients who were correctly vaccinated, that is, $7.14 \%$. Data on vaccination status of patients from the studied group, born in the period from 1985 to 1996 : in $55.14 \%$ of 
respondents, there was no data on vaccination and only $24.3 \%$ of the subjects were vaccinated with a single dose of vaccine. Two doses of vaccine were received by $12.15 \%$ of the respondents. $8.41 \%$ of the respondents were not vaccinated at all. $(n=107)$

Data on vaccination status of patients from studied groups born before 1985 or after 1996: in 39.39\% of respondents, we did not have information about immunization. 33.33\% of respondents were not vaccinated at all. Vaccination was done with one dose of vaccine in $24.24 \%$ of the respondents, and with two doses in $3.03 \%$ of the respondents. $(n=33)$.

Table 3. Sex distribution of patients in the experimental group according to their vaccination status

\begin{tabular}{|c|c|c|c|c|c|c|}
\hline \multirow{3}{*}{ Sex } & \multicolumn{6}{|c|}{ Vaccination of patients in the experimental group } \\
\hline & \multicolumn{4}{|c|}{$\begin{array}{c}\text { Not fully } \\
\text { Fully vaccinated vaccinated (1 } \\
\text { vaccination) }\end{array}$} & \multicolumn{2}{|c|}{$\begin{array}{l}\text { Unvaccinated } \\
\text { (no vaccination }\end{array}$} \\
\hline & $\mathrm{n}$ & $\%$ & $\mathrm{n}$ & $\%$ & $\mathrm{n}$ & $\%$ \\
\hline Male & 6 & 60.00 & 27 & 79.41 & 16 & 66.67 \\
\hline Female & 4 & 40.00 & 7 & 20.59 & 8 & 33.33 \\
\hline Total & 10 & 100.00 & 34 & 100.00 & 24 & 100.00 \\
\hline
\end{tabular}

\section{Discussion}

The average age of patients with mumps is generally greater than the age of patients with enterovirus meningitis ${ }^{22,23}$ and this was confirmed in our study as well. Mumps occurred in all age groups, however, adolescents and young adults aged between 15 and 24 years, who weren't correctly vaccinated, were most affected, ${ }^{1,18,24}$ and thanks to the community immunity, they weren't exposed to wild-type. ${ }^{1}$ Younger children still get enterovirus infections since there is no enterovirus vaccine. ${ }^{24}$

According to the information from the Public Health Institute of Republic of Srpska along with the information from our study, the most affected group of people during the mumps epidemic were those who were supposed to be vaccinated against mumps from 1992 to 1998 , when there was no regular supply of MMR vaccine, and therefore, there was no regular vaccination. If unimmunized person is only an isolated case in the community, that person is usually protected by the community immunity, but if most of the population in the community is not immunized the risk of epidemic is significantly higher.$^{25}$

Both mumps meningitis ${ }^{2,18}$ and enteroviral meningitis ${ }^{26}$ are more common in men, regarding their vaccinal status, and that was also confirmed in our study. It is known that other viral meningitis is also more common in men than women. ${ }^{27}$ The possible reasons are that women more often have subclinical infections, or that men are likely to tolerate pain less than women, but the real reason still remains unknown. ${ }^{28}$

Adequate vaccination is the most important strategy for mumps prevention. ${ }^{4}$ If $90 \%$ and more children is fully vaccinated against mumps, mumps epidemic can be prevented.7 Vaccination failure gives contribution to the mumps outbreak ${ }^{3}$ because in contact with wild-type of virus, not only those who weren't vaccinated would get mumps infection, but also those who were incompletely vaccinated or those who were completely vaccinated but with low titer antibodies against mumps, usually because of primary (lack of immune response to vaccine) or secondary (vaccine immunity wane over time) vaccine failure as well as the different ability of vaccine induced antibodies to neutralize different virus genotypes. ${ }^{29}$ Those people who received only one dose of vaccine are at higher risk for mumps infection than those who received two doses of the vaccine..$^{30}$ Even people who received two doses of mumps vaccine might not be protected against mumps because of decrease in level of antibodies, which highlights the importance of heightened clinical awareness and timely reporting of suspected mumps cases. ${ }^{15}$

Most patients with mumps meningitis in mumps epidemic during 2011 and 2012 in Republic of Srpska were born from 1985 to 1996 , which was caused by described vaccination omissions in the war and early post-war period. For most of these patients we couldn't get information about their vaccination status, which was probably the consequence of the war and population migration. All of those people who managed to receive one dose of the vaccine against mumps received it either before 1992 or with delay, after 1998, and small percentage received the second dose of the vaccine when it became available. We couldn't get information about vaccination status for great percentage of patients in the experimental group who were born before or after the period mentioned above. According to information form the Public Health Institute of Republic of Srpska, mumps vaccination in our territory has been conducted since the 80 's, so the patients born before that period did not have the opportunity to receive the mumps vaccine according to the immunization schedule. All of these information show that different factors can have an impact on overall low population mumps vaccine coverage and therefore on possible mumps infection.

\section{Conclusion}

Nowadays, the patients with mumps meningitis are older than the patients with serous meningitis of other etiology, probably enteroviral. During the epidemic of mumps in 2011 and 2012 in Republic of Srpska, there were significantly more patients with mumps meningitis who were supposed to be vaccinated in the war and early post-war period than those who were supposed to be vaccinated before or after 
this period. This epidemic is a consequence of maintaining the virus in unvaccinated population, mainly because of the omissions made during the war and early post-war period, and insufficient duration of protection after vaccination, especially in vaccination with one dose of the vaccine.

\section{References}

1. Hindiyeh MY, Aboudy Y, Wohoush M, Shulman LM, Ram D, Levin T, et al. Characterization of Large Mumps Outbreak among Vaccinated Palestinian Refugees. J. Clin. Microbiol. 2009; 47: 560-5.

2. Rubin S, Carbone KM. Mumps. In: Longo D, Fauci A, Kasper D, Hauser S, Jameson J, Loscalzo I. Harrison's Principles of Internal Medicine, 18th Edition. Professional\&Medical, 2011: 3265-71.

3. Defendi GL. Mumps. Last updated: Feb 6, 2012. Available from: http://reference.medscape.com/article/966678-overview (last accessed 16.02.2014.)

4. Kutty PK, Kyaw MH, Dayan GH, Brady MT, Bocchini JA, Reef SE, et al. Guidance for Isolation Precautions for Mumps in the United States: a Review of the Scientific Basis for Policy Change. CID 2010; 50: 1619-28.

5. Hrynash Y, Nadraga A, Dasho M. Effectiveness of a vaccination program against mumps in Ukraine. Eur J Clin Microbiol Infect Dis. 2008; 27: 1171-6.

6. Mackenzie DG, Craig G, Moore J. Mumps in a boarding school: description of an outbreak and control measures. Br J Gen Pract. 2006; 56: 526-9.

7. Choi KM. Reemergence of mumps. Korean J Pediatr. 2010; 53: 623-8.

8. Shanley JD. The resurgence of mumps in young adults and adolescents. Cleve Clin J Med 2007; 74: 42-6.

9. Centers for Disease Control and Prevention web site.

Mumps Outbreak on a University Campus - California 2011. MMWR 2012; 61: 986-9.

Available from: http://www.cdc.gov/mmwr/preview/mmwrht$\mathrm{ml} / \mathrm{mm} 6148 \mathrm{a} 2 . \mathrm{htm}$

(Last accessed 16.02.2014.)

10. Vince A. Virus mumpsa. U: Begovac J, Božinović D, Lisić M, Barišić B, Schonwald S. Infektologija. Zagreb: Profil international, 2006: 465-70.

11. Sauder C, Zhang CX, Ngo L, Werner K, Lemon K, Duprex WP, et al. Gene-Specific Contributions to Mumps Virus Neurovirulence and Neuroattenuation. J.Virol. 2011; 85: 7059-69.

12. Božinović D. Akutni meningitis. U: Begovac J, Božinović D, Lisić M, Barišić B, Schonwald S. Infektologija. Zagreb: Profil international 2006: 228-32.

13. Quinlisk MP. Mumps Control Today. JID 2010; 202: 656-6.

14. Borchardt SM, Rao P, Dworkin MS. Compliance with Exclusion Requirements to Prevent Mumps Transmission. Emerg Infect Dis. 2007; 13: 1617-8.

15. Vaishampayan J, Dailey L, Cusick J, Galleos-Jackson E, Penning L, Stoll P. Mumps Outbreak on a University Campus-California, 2011. JAMA 2013; 309: 650-3.
16. Ministarstvo zdravlja i socijalne zaštite Republike Srpske. Program mjera za sprečavanje i eliminaciju i eradikaciju zaraznih bolesti za područje Republike Srpskeza 2013. godinu.

17. Yung CF, Andrews N, Bukasa A, Brown KE, Ramsay M. Mumps Complications and Effects of Mumps Vaccination, England and Wales, 2002-2006. Emerg Infect Dis. 2011; 17: 661-7.

18. European Centre for Disease Prevention and Control. Annual epidemiological report 2013. Reporting on 2011 surveillance data and 2012 epidemic intelligence data. Stockholm: ECDC; 2013. Available from:

http://www.ecdc.europa.eu/en/publications/Publications/annual-epidemiological-report-2013.pdf (last accessed 16.02.2014.)

19. Javna zdravstvena ustanova Institut za javno zdravstvo. Zdravstveno stanje stanovništva u Republici Srpskoj za 2011. godinu. JZU Institut za javno zdravstvo, Republika Srpska.

20. Javna zdravstvena ustanova Institut za javno zdravstvo. Zarazne i parazitarne bolesti na teritoriji Republike Srpske u 2012. godini. JZU Institut za javno zdravstvo, Republika Srpska.

21. Hukić M, Ravlija J, Dedeić Ljubović A, Moro A, Arapčić S, Muller $\mathrm{CP}$, et al. Ongoing large mumps outbreak in the Federation of Bosnia and Herzegovina, Bosnia and Herzegovina, December 2010 to July 2011. Euro Surveill. 2011; 16:pii=19959.

22. Asano T, Ichiki K, Koizumi S, Kaizu K, Hatori T, Fujio O, et al. Enhanced expression of cytokines/chemokines in cerebrospinal fluids in mumps meningitis in children. Pediatrics International 2011; 53: 143-6.

23. Benić B. Coxsackievirusi, echovirusi i noviji enterovirusi. U: Begovac J, Božinović D, Lisić M, Barišić B, Schonwald S. Infektologija. Zagreb: Profil international 2006: 509-19.

24. Centers for Disease Control and Prevention web site. Viral Meningitis. Last updated: March 15, 2012. Available from: http://www.cdc.gov/meningitis/viral.html (last accessed 16.02.2014.)

25. Van der Wal MF, Diepenmaat ACM, Pel JM, Hirasing RA. Vaccination rates in a multicultural population. Arch Dis Child 2005; $36-40$.

26. Dommergues MA, Harzic M, Gobert ME, et al. Seasonal outbreak of enteroviral meningitis during summer 2005: experience of a French pediatric unit. Arch Pediatr.2007; 14: 964-70.

27. Hviid A, Melbye M. The epidemiology of viral meningitis hospitalization in childhood. Epidemiology 2007; 18: 695-701.

28. Leboreiro-Fernandez A, L Moura-Ribeiro MV, Leboreiro IEF, Sawan FM, Ventura AR, Barbosa KCK. Mumps meningoencephalitis. An Epidemiological approach. Arq Neuropsiquiatr 1997; 55: 12-5.

29. Latner DR, McGrew M, Wiliams N, Lowe L, Werman R, Warnock E. Enzyme-Linked Immunospot Assay Detection of MumpsSpecific Antibody-Secreting B Cells as an Alternative Method of Laboratory Diagnosis. Clin Vaccine Immunol. 2011; 18: 35-42.

30. Stanley J. Illinois health officials investigating 2014 mumps outbreak. Available from:

http://news.medill.northwestern.edu/chicago/news. aspx?id=230055

(last accessed 26.04.2014. 


\section{Epidemiološke karakteristike meningitisa izazvanog virusom mumps-a u toku epidemije u Republici Srpskoj}

\section{SAŽETAK}

Uvod: Mumps je sistemska virusna infekcija koju karakteriše otok pljuvačnih žlijezda, najčešće parotidnih, a može zahvatiti i gonade, moždane ovojnice, gušteraču i druge organe.

Cilj rada: Cilj rada je bio analiza epidemioloških karakteristika mumps meningitisa u posljednjoj epidemije mumpsa u Republici Srpskoj, te analiza učestalosti mumps meningitisa i vakcinalnog statusa kod ispitanika koji su protiv mumpsa trebali biti vakcinisani u ratnom i ranom poslijeratnom periodu, i onih koji su trebali biti vakcinisani prije ili poslije tog perioda.

Ispitanici i metode: Uključeno je 175 pacijenata podjeljenih u ispitivanu (140 pacijenata oboljelih od mumps meningitisa) i kontrolnu (35 pacijenata oboljelih od seroznog meningitisa druge, najvjerovatnije enterovirusne etiologije) grupu. Poredili smo epidemiološke karakteristike oboljelih. Dodatno su analizirane razlike u navedenim karakteristikama mumps meningitisa između oboljelih prethodno različitog vakcinalnog statusa.

Rezultati: Srednja vrijednost životne dobi oboljelih ispitivane grupe je bila 20.0 godina (18.0-24.5; IQ), a kontrolne 7.0 godina (5.014.0; IQ) ( $p<0.001)$. Oboljeli rođeni od 1985. do 1996. godine su statistički značajno više ( $p<0.001)$ imali mumps meningitis od ostalih oboljelih ispitivane grupe. Nije uočena statistički značajna razlika u polnoj distribuciji između oboljelih ispitivane i kontrolne

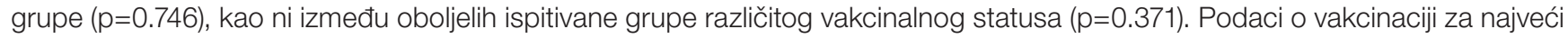
broj oboljelih ispitivane grupe su bili nedostupni, zatim slijede oboljeli koji su primili samo jednu dozu vakcine, nevakcinisani te potpuno vakcinisani.

Zaključak: Navedena epidemija mumpsa tokom 2011. i 2012. godine je posljedica održavanja virusa u nevakcinisanoj populaciji, uglavnom zbog propusta nastalih u ratnim i ranim poslijeratnim godinama i nedovoljno duge zaštite nakon vakcinacije, prije svega jednokratne.

Ključne riječi: mumps, meningitis, epidemija 